Maja Gligorić ${ }^{1}$

Vule Mizdraković ${ }^{2}$

Ivana Mitrašinović ${ }^{3}$

Valentina Bošković Marković ${ }^{4}$
JEL: M42

DOI:10.5937/industrija47-24095

UDC:657.631.6:334.72(497.11)"2017"

005.52:005.33

Original Scientific Paper

\title{
Audit Timeliness and Market Capitalization: Evidence from an Emerging Market ${ }^{5}$
}

\author{
Article history: \\ Received: 20 October 2019 \\ Sent for revision: 31 October 2019 \\ Received in revised form: 2 December 2019 \\ Accepted: 3 December 2019 \\ Available online: 31 December 2019
}

\begin{abstract}
This paper analyses the lag of audit reports for companies included on Belgrade Stock Exchange (BELEX). Its purpose is to define which of listed variables have an influence on the length of time between the end of the financial reporting period and the date the audit report is made public. The research sample includes 400 firm year observations for 2017, representing approximately $70 \%$ of the total number of public companies on the BELEX. The results are interpreted through descriptive analysis, correlation analysis between the given variables, and linear regression. Based on these results, the authors created a model which highlights critical factors in estimating Audit Report Lag (ARL). Research results have shown that the level of market capitalization represents a statistically significant variable for predicting ARL. Companies with higher market capitalization can expect reports more quickly than other companies. Research results may assist prospective and existing investors when analysing investment risks related to the accuracy and reliability of information presented in financial statements. Regarding its contribution, this paper is considered original as it is the first paper that analyses the factors affecting ARL in the Republic of Serbia.
\end{abstract}

Keywords: Audit Report Lag, Audit Report Delay, Financial statements, Audit opinion, Public companies

\footnotetext{
${ }^{1}$ Singidunum University

${ }^{2}$ Singidunum University, vmizdrakovic@singidunum.ac.rs

${ }^{3}$ Singidunum University

${ }^{4}$ Singidunum University

5 This research is part of the project no. 179001, for the period 2011-2019, financed by the Ministry of Education, Science and Technological Development of the Republic of Serbia.
} 
Gligorić M. et al.: Audit Timeliness and Market Capitalization: Evidence from an...

\section{Pravovremenost revizije i tržišna kapitalizacija na primeru jednog tržišta u razvoju}

Apstrakt: $U$ ovom radu je analizirano kašnjenje izveštaja eksternih revizora za javna privredna društva sa Beogradske berze koja posluju na teritoriji Republike Srbije. Svrha rada je određivanje varijabli koje utiču na dužinu perioda od datuma na koji glase finansijski izveštaji do datuma dostavljanja revizorskog mišljenja. Uzorak istraživanja se sastoji od 400 finansijskih izveštaja i pripadajućih revizorskih izveštaja za izveštajni period 2017. godine, što predstavlja skoro $70 \%$ ukupnog broja javnih društava. Prikazani su rezultati deskriptivne analize, analize korelacije između posmatranih varijabli $i$ linearne regresije na osnovu koje je kreiran model koji upućuje na najznačajnije faktore koji određuju kašnjenje revizije - Audit Report Lag (ARL). Rezultati istraživanja pokazuju da, pored ostalih, visina tržišne kapitalizacije predstavlja statistički značajnu varijablu za predviđanje dužine trajanja ARL $i$ da javna društva sa većom tržišnom kapitalizacijom mogu očekivati izveštaj ranije od ostalih. Rezultati istraživanja bi trebalo da budu od pomoći potencijalnim $i$ postojećim investitorima $u$ analizi nivoa rizika investicija, vezano za tačnost $i$ pouzdanost informacija prikazanih $u$ finansijskim izveštajima. U pogledu doprinosa, ovaj rad se smatra originalnim, jer se po prvi put istražuju faktori koji utiču na dužinu ARL u Republici Srbiji.

Ključne reči: ARL, ARD, finansijski izveštaji, revizorsko mišljenje, pravovremenost finansijskog izveštavanja, javna društva

\section{Introduction}

Audit opinion is exceptionally valuable for both internal and external stakeholders who are interested in the operations of a company. Financial statements are used by current and prospective investors to analyse the level of risk and profitability. Statements are also used to evaluate prospective companies with whom to cooperate. For publicly traded companies, financial statements are one of the primary sources of information upon which credit ratings are determined and are utilized by investors in determining whether to invest in securities. Financial statements are not published before an independent audit is completed and any delay between the end of the reporting period and delivery date of audit report may impact the value of the information. It is in the best interest of company management to prepare financial statements and to share audit reports as quickly as possible as prospective investors utilize this information in their decision-making process and current investors use this information to evaluate their investments. Audited financial reports are critical resources used in determining market effectiveness, investment priorities, investment risk evaluation, and for 
Gligorić M. et al.: Audit Timeliness and Market Capitalization: Evidence from an...

improving the quality of stakeholders' decisions. As such, investors consider the quality of financial statements during investment risk assessment. An ARD may highlight an underlying issue with company operations and signal to prospective investors an elevated investment risk.

Many investors are interested in companies that have low market capitalization. While these companies offer a greater opportunity for higher investment returns, they also come with greater investment risk. The company hired to complete the financial audit will generally identify the level of financial risk and implement a greater number of audit procedures in those them deem higher risk. This is done to ensure the auditor has the required data to fully assess the risk. Companies with high market capitalisation are usually larger companies and are often parts of business groups. These companies will have complex transactions between the groups which could increase audit risk and increase the time required for the audit process to be completed (Azami and Salehi, 2016). As a result of the above-mentioned complexities impacting the audit process, there may be gaps and delays. This is referred to as an "audit report lag" (Ezat, 2015). The delay between the financial reports date and the audit opinion date should be minimized to ensure the information is still valuable for decision-makers. If there is a significant delay in delivering an audit opinion, it could create potential uncertainty regarding economic, financial, and investment decisions (Sarraf, et al., 2015). In contemporary business, timeliness and availability of information plays a significant role in the decision-making process as it enables investors to discover investment opportunities and potential investment risks. Therefore, it is necessary for investors to pay attention to ARL and to factors which might affect it.

The focus of the research in this paper is to assess the connection between $A R L$ and market capitalization. It is important to note that investors can perceive ARL as a signal that the financial reports may not be fair and objective. As already mentioned, this perspective may not be accurate in certain cases as companies with higher investment opportunities are often subjected to increased audit scope due to the complexity of their business processes. As such, longer audits should be expected in some situations (Ashton, et al., 1987). Many studies have shown that larger entities have strong internal financial controls which auditors rely on. This often decreases the scope of the audit and decreases the length of the auditing process (Ashton, et al., 1989), (Carslaw and Kaplan, 1991), (Ahmed, 2003), (Afify, 2009), (Al-Ghanem and Hegazy, 2011), (Modugu, et al., 2012), (Sarraf, et al., 2015). The objective of investors is to invest their capital in profitable and secure businesses. Accurate financial reports provide critical information to make these informed investment decisions. Foreign direct investments (FDI) are an important part of capital market development. Serbian market is no exception, as it has been confirmed that FDI led to productivity growth of many companies (Boljanovic \& Hadzic, 2017). 
Gligorić M. et al.: Audit Timeliness and Market Capitalization: Evidence from an...

There are many factors which can delay audit report delivery. These factors will likely differ between established financial markets and developing economies, companies of varying size, and different business sectors. In developing markets it is more difficult to anticipate market fluctuations, determine the quality of financial and audit reporting, and ultimately to assess investment risk. As such, developing markets should be analysed more thoroughly. The focus of this research is on companies listed on Belgrade Stock Exchange (BELEX). By analysing their ARL, and the factors that affect its increased or decreased stock value, the authors have identified factors that have a significant influence on ARL. The research results may assist prospective and existing investors to better understand and analyse audit reports and support audit clients in achieving better financial results indirectly. Considering the importance of receiving audit reports in timely manner, identifying the factors that create delays in reporting financials to the public will also be very helpful.

Based on the previous statements, the first research question is: What factors are responsible for the length of ARL in public companies in the Republic of Serbia? As this paper studies the opportunities to invest in public companies and the timeliness of audit report, the second research question is: Do companies which have high market capitalization have shorter ARL? The following section offers literature review. The research methodology is then presented along with the defined research variables. Prior to conclusion, the paper offers research results and discussion.

\section{Literature review}

The review starts with Asian countries. Author Al-Ajmi (2008) has included 11 independent variables in his model, while the dependent variable is the Auditors' signature period. The sample includes public companies whose stocks are listed on Bahrain Stock Exchange during the period from 19922006. The author notices that $91 \%$ of public companies choose one of the Big 4 auditing companies, while other factors which are found relevant for the length of ARL are: Company size, Profitability, and Business leverage. Furthermore, there was no evidence which would support the influence of accounting complexity or auditor type (the Big 4, non-Big 4 companies). Ahmed (2003) has studied the timeliness of annual reporting in three South Asian countries: Bangladesh, India and Pakistan, during 1998. His study shows that if public companies from India and Pakistan hire auditing services from big auditing companies, ARL decreases. However, only in Pakistan did the Profitability variable and Corporation size have a significant correlation with ARL. 
Gligorić M. et al.: Audit Timeliness and Market Capitalization: Evidence from an...

Jaggi and Tsuo (1999) utilized a study conducted on a sample of public companies from Hong Kong in the period from 1991-1993. The authors noticed a difference between the length of ARL in industrial sectors. The average ARL is the longest in the manufacturing sector (112.94 days), and the shortest in utility services (60.14 days). The results also showed that variations in average ARL for different industrial groups are not significant apart from utility services. Variations in average ARL ranged from 92.41 days (transportation and communication) to 112.94 days (manufacturing). Authors Lee, H. Y. \& Jahng, G.-J. (2008) utilized Korean public companies as their research sample. The authors used 17 independent variables in their model, with $A R L$ as the dependent variable. Their researched identified that the dependent variable ARL had a negative and significant correlation with the following variables: Non-audit fees which are paid to the incumbent auditors, Auditor type and Modified audit opinion.

Public companies listed on Indonesia Stock Exchange (ISE) have been studied by authors Iskandar and Trisnawati (2010) during the period 20032009. The authors included six independent variables in their model, with report delay as a dependent variable. The results showed that in the Industrial sector, Net result and the size of Public Accounting Firms, often have an influence on the length of ARL. However, the authors emphasised that the Size of the audit client, the Audit opinion type and the amount of Debt proportion were not significant factors. In the research conducted on public companies listed on Malaysia stock exchange, authors Che-Ahmad and Abidin (2008) included 11 independent variables in their model, with ARD as the the dependent variable. The study proved that the following factors were significant for determining the dependent variable: Total assets, Number of subsidiaries, Auditor type, Audit opinion, Return on equity and the amount of stock owned by company management.

Authors Khalid and Qais (2012) conducted a study of public companies listed on the Jordanian Stock Exchange at the end of the fiscal year, December 31st, 2010. The authors formed two models: one for the service sector, and another for the industrial sector. Five independent variables were included in the first sector with ARD as the dependent variable. The study showed that the following factors were negatively correlated with ARL: Profitability ratio, Auditor type and Auditor client size. The model for the industrial sector consisted of the following factors which were negatively correlated with the dependent variable: Profitability ratio, Auditor type, Auditor client size and Financial leverage. When it comes to Iranian public companies, Azami and Salehi (2016) analysed those listed on Tehran Stock Exchange (TSE) during the period 2006-2014. The authors included eight independent variables in their model, with ARL as the dependent variable. According to these authors, legal entities with higher investment opportunities and financial issues or flaws in internal controls, have longer ARL. ARL is also longer when there is a 
Gligorić M. et al.: Audit Timeliness and Market Capitalization: Evidence from an...

change in independent auditor. Author (Hassan, 2016) analysed a sample of public companies listed on Palestine Stock Exchange (PSE) during 2011. The results showed that there are numerous factors which impacted the ARD, including Auditor client size, Board size, Auditor type, Existence of auditing committee and Ownership dispersion.

Three African countries appear in this literature review and the first one is Egypt. Afify (2009) has studied public companies listed on Alexandria Stock Exchange in 2009. The author used a model with eight independent variables where three variables were identified as having a significant influence on the length of ARL. The variables; Auditor client size, Industrial sector and Profitability had a significant negative correlation with ARL. Other variables in the model were not significantly correlated with the length of ARL. In the reported study, the author (Ezat, 2015) used non-financial companies listed on the Egyptian stock exchange in the period from 2011 to 2013 as a sample. The author chose a model of twelve independent variables, where seven variables were identified as having a significant influence on audit lag. The study shows that $A R L$ was positive and significantly correlated with the variables Company size, Leverage, Number of subsidiaries and Governmental ownership. On the other hand, ARL had a negative and statistically significant correlation with the variables: Audit opinion, Auditor fees, Joint auditors, Managerial ownership and Private ownership. Authors Akingunola, et al. (2018) analysed a sample of public companies listed on Nigeria Stock Exchange (RMS). The authors included four independent variables in their model, while the dependent variable was $A R L$. As in the previous studies, this study identified that Auditor client size, Company age, Auditor type and Profitability had a significant influence on the length of ARL.

When it comes to European countries, Leventis, et al. (2005) used public Greek companies listed on Athens Stock Exchange up untill December 31st, 2000 as their sample. The authors chose a model of thirteen independent variables, where ARL was the dependent variable. The study showed that the following factors are important when determining the dependent variable: Auditor type, Audit fee, Number of auditing remarks, Extraordinary transactions or bills and Expressed uncertainties in audit opinion. Furthermore, the results showed that $A R L$ is likely to be shorter if the audit is done by an international auditing company or if additional fees are paid, while $A R L$ will be longer if there are issues identified regarding the company's business. Authors Bonson-Ponte, et al. (2008) conducted a study of public companies in the Spanish market during the period 2002-2005. The study identified that the timeliness of audit reporting was impacted by the level of regulatory pressure and organizational size. The authors also identified that the variables; Auditor type, Auditor qualifications and Normative change, did not have a significant correlation with ARL. The results of the study conducted by a team of authors in the Serbian market (Obradović, et al., 2018) identified 
Gligorić M. et al.: Audit Timeliness and Market Capitalization: Evidence from an...

that $A R L$ is longer for auditing companies who utilized one of the the Big 4 auditing companies than for those who utilized other auditing companies.

In the research conducted on New Zealand stock exchange for the years 1987 and 1988, authors Carslaw and Kaplan (1991) utilized a model with nine independent variables, where 5 out of 9 variables had a significant influence on the length of ARL. The study showed that audit delay had a positive correlation with the variables: Income, Extraordinary item and Audit opinion. On the other hand, audit delay had a negative correlation with the variables Auditor client size and Company ownership. As for the other four dependent variables, two out of four coefficients were as predicted.

When it comes to North America, authors Ashton, et al. (1989) have taken public companies, whose stocks are listed on Toronto Stock Exchange during the period from 1977-1982, as a sample for their study. The authors noticed the difference in the length of ARL for companies whose audit had been done by one of the Big 9 auditing companies. Namely, it has been noticed that the highest average ARL within the Big 9 is still shorter than the average ARL for the reports completed by smaller auditing companies. Finally, authors Pham, et al. (2014) analyzed a sample of public companies in the USA during the period 2010-2012. The authors included ten independent variables in their model. Nine variables were identified as having a significant correlation with the dependent variable ARL. The dependent variable had a positive correlation with the following variables: Investment opportunities, Loss above capital (LOSS), Going concern and Auditor change. The dependent variable had a negative and significant correlation with the following independent variables: Net earnings divided by total assets (ROA), the Big 4, and Audior client size.

\section{Methodology}

\subsection{Research sample and data}

The research for this paper was conducted to answer the questions stated in the introduction. The authors analysed the reports of 400 companies in the Republic of Serbia listed on BELEX. Initially the study included all 582 public companies listed on the Serbian stock exchange on October 19, 2018. However, the number of the companies included in the study was reduced due to the exclusion of banks and other financial institutions which follow different accounting regulations and prepare financial statements using unique reporting forms. In addition, companies with missing financial reports, and/or audit reports, were also excluded from the study. As a result of eliminating the above-mentioned companies, the sample consisted of 400 public companies which represented approximately $70 \%(68.73 \%)$ of all legal entities on the stock exchange at that time. The financial statements and the 
Gligorić M. et al.: Audit Timeliness and Market Capitalization: Evidence from an...

existing audit reports for these companies were collected from the database of the Serbian Business Registers Agency (SBRA) for the reporting period 2017. It is important to note that audit reports refer to specific, and not consolidated, financial statements. Because the financial statements were presented in the national currency, the values were converted into a more stable currency (the euro) using the exchange rate on December 31st, 2017. It should be mentioned that for the same reporting period, two other studies have been performed on similar number of entities from Belgrade Exchange Stock (Mitic, Kokic, Mizdrakovic, \& Tereladze, 2019), (Gligoric, Mizdrakovic, Kostic, \& Grzinic, 2019).

Table 1. Measurement of the explanatory variables

\begin{tabular}{|c|c|c|}
\hline Variables & Acronym & Proxy \\
\hline Audit report lag & $A R L$ & $\begin{array}{l}\text { The period between a company's } \\
\text { fiscal year end and the audit report } \\
\text { date }\end{array}$ \\
\hline Industry type & Ind & $1=$ Non-industry $0=$ Industry \\
\hline Market Capitalization & $\mathrm{MaC}$ & $\begin{array}{l}\text { Value per share times } \times \text { Number of } \\
\text { shares }\end{array}$ \\
\hline Un/Modification & Mod & $1=$ Modified $0=$ Unmodified \\
\hline Average number of employees & NoE & Number of employees per month \\
\hline Auditor type & Aud & $1=\operatorname{Big} 40=$ non-Big 4 \\
\hline Company size & Size & Natural log total assets \\
\hline Sales revenue & SRev & Natural log sales revenue \\
\hline Current ratio & CRat & Current assets to short term liabilities \\
\hline Net working capital & NWC & $\begin{array}{lllll}\begin{array}{l}\text { Current } \\
\text { liabilities }\end{array} & \text { assets less short } & \text { term } \\
\end{array}$ \\
\hline Loss above capital & LOSS & $\begin{array}{l}\text { Liabilities higher than total assets } \\
(1=\text { LOSS, } 0=\text { No LOSS) }\end{array}$ \\
\hline Debt ratio & DRat & Total liabilities to total assets \\
\hline Net margin & $\mathrm{NMa}$ & Net result to total revenue \\
\hline Gross margin & GMa & Revenue less COGS to revenue \\
\hline EBITDA & EBITDA & $\begin{array}{l}\text { Natural log of } \text { Earnings Before } \\
\text { Interest, Taxes, Depreciation and } \\
\text { Amortization }\end{array}$ \\
\hline Sales to total assets & STA & Sales revenue to total assets \\
\hline Altman Z score & AZS & Per original formula \\
\hline Zmijewski score & ZMS & Per formula \\
\hline
\end{tabular}

Source: Authors research

Financial indicators, which might be connected to $A R L$, have been calculated in accordance with the existing theoretical approaches. 
Gligorić M. et al.: Audit Timeliness and Market Capitalization: Evidence from an...

The following table presents the variables which might affect ARL. These variables have been chosen based on the most significant factors recognized in the previous studies outlined in the literature overview. Additional variables, not mentioned to this point, have also been included.

The variables presented in the table above will be explained in more detail later in this paper.

\subsection{Variables and analysis}

\subsubsection{Auditor client size}

Previous studies have shown that company size is one of the most commonly used variables in determining audit timelines for public companies. Company size is usually measured by the value of total assets of the studied company presented in natural logarithm (Al-Ghanem and Hegazy, 2011), (Khasharmeh and Aljifri, 2010), (Che-Ahmad and Abidin, 2008), (Al-Ajmi, 2008), (BonsonPonte, et al., 2008), (Naser, et al., 2007), (Owusu-Ansah and Leventis, 2006), (Leventis and Weetman, 2004), (Owusu-Ansah, 2000), (Abdulla, 1996), (Bamber, et al., 1993), (Ashton, et al., 1987), (Givoly and Palmon, 1982), (Davies and Whittered, 1980) (Alkhatib and Marji, 2012), (Courtis, 1976). Large companies usually utilize the services of one of the Big 4 auditing firms as they are considered to have more efficient procedures and techniques for collecting audit evidence resulting in more reliable audit opinions. This also increases the level of reliability of the financial statements. Auditing processes are more complex and demanding for larger companies because they have more business activities. Studies conducted have shown both statistically significant and insignificant correlations between timeliness of audit reports and company size. There are a significant number of studies which have identified relevant statistical correlations (Courtis, 1976), (Ashton, et al., 1989), (Bamber, et al., 1993), (Abdulla, 1996), (Leventis and Weetman, 2004), (Owusu-Ansah and Leventis, 2006), (Al-Ajmi, 2008), (Che-Ahmad and Abidin, 2008). There are also studies that identify insignificant correlations (AlGhanem and Hegazy, 2011), (Khasharmeh and Aljifri, 2010), (Owusu-Ansah, 2000), (Givoly and Palmon, 1982), (Davies and Whittered, 1980).

\subsubsection{Industry type and market capitalization}

The level of inherent risk in the auditing process is directly correlated to the industry the company is in. Therefore, it can be expected that ARL will differ between various industrial sectors. The companies studied on Belgrade Stock Exchange have been categorized into two main sectors: industry and 
Gligorić M. et al.: Audit Timeliness and Market Capitalization: Evidence from an...

services. 227 companies from the industrial sector, approximately $56 \%$ of the companies studied, and 182 companies from the service sector, approximately $44 \%$ of the companies studied, were chosen for the purpose of this selected for this study. Most authors from this field of expertise (Cooke, 1989), (Khasharmeh and Aljifri, 2010), (Owusu-Ansah and Leventis, 2006), (Carslaw and Kaplan, 1991), (Ashton, et al., 1989), (Ashton, et al., 1987) excluded banks and financial institutions from their samples because of different regulations and auditing processes. This study also eliminated banks and financial institutions for the same reasons.

Market capitalization is one of the key parameters used when analysing the capacity and performances of a market. Market capitalization is an indicator of the size and scope of turnover on the stock exchange and is determined by multiplying the market price of all stocks and the overall number of shares. These data can serve as an introduction to the size of the studied market, as well as to the potential of investing in such a location (Belgrade Stock Exchange, 2019).

\subsubsection{Auditor type}

There are two types of auditing companies which can offer auditing services, i.e. checking financial reports: the Big 4 companies and other auditing companies. History has shown that large and middle-sized companies usually hire the Big 4 auditing companies due to the complexity of their business processes. In some cases, the decision to hire one of the Big 4 may be due to legislation requiring that the audit of bigger companies be conducted by auditing companies with a greater number of certified independent auditors. As it has previously been mentioned, audits performed by the Big 4 may offer more credible financial statements. This is why the Big 4, when compared to non-Big 4 auditors, earn a higher level of stakeholders' trust. Previous studies have shown contradictory results when attempting to correlate the of type of auditor and the length of ARL. Some authors (Alkhatib and Marji, 2012), (Enofe, et al., 2013) have confirmed significant positive correlation between the type of auditor and the length of ARL. Authors (Ashton, et al., 1989), (Ahmed, 2003), (Al-Ghanem and Hegazy, 2011), (Leventis, et al., 2005), (Lee and Jahng, 2008), (Shukeri and Islam, 2012), (Ezat, 2015) alternatively highlighted negative correlation between the type of auditor and the length of ARL. There are also studies identifying no statistically relevant correlation between the type of auditor and the length of ARL (Carslaw and Kaplan, 1991), (Hossain and Taylor, 1998), (Lai and Cheuk, 2005), (Bonson-Ponte, et al., 2008), (Che-Ahmad and Abidin, 2008) (Afify, 2009), (Al-Ajmi, 2008), (ElDyasty, 2011), (Hashim and Rahman, 2011), (Vuko and Cular, 2014), (Azubike and Aggreh, 2014). 
Gligorić M. et al.: Audit Timeliness and Market Capitalization: Evidence from an...

The majority of financial report auditing in this study was conducted by nonBig 4 auditing firms. 370 companies representing $92.50 \%$ of the overall study sample were audited by non-Big 4 auditing firms while 30 companies, representing $7.50 \%$ of the overall study sample, were audited by one of the Big 4. The results identified that ARL is longer for companies which hired one of the Big 4 to complete their audit with an average of 118 days. The average number of days of ARL for companies whose audit was completed by non-Big 4 companies was 110 . It is important to note that there are companies with a significantly shorter ARL in the first group, while there are companies with significantly longer $A R L$ than the average as well. There are numerous reasons why only a few companies hire the Big 4 . Most often, it is due to the high price of the Big 4 auditing services and due to financial constraints that business entities in developing markets might have. Large business entities are usually more financially stable than other entities. In the Republic of Serbia, $0.32 \%$ of all companies are large entities, $1.29 \%$ middle-sized entities, $9.42 \%$ fall under small entities, and the remaining $88.98 \%$ represent microlegal entities (the Serbian Business Register Agency, 2018). All large and middle-sized entities are obligated to audit their financial reports. However, small and micro-legal entities whose stocks are listed on the stock exchange have to perform mandatory audit as well. When it comes to the research sample in this paper, only $9.25 \%$ of the overall sample is large entities, $20.00 \%$ of them are middle-sized entities, $33.00 \%$ are small entities, and $37.75 \%$ of them are micro entities.

\subsubsection{Audit opinion}

An independent auditor is required to give an opinion about whether financial reports represent true and fair state of companies' financial results. They also verify whether these reports have been created in accordance with suitable regulations regarding financial reporting. There are modified and unmodified audit opinions. Unmodified audit opinions are provided when auditors confirm that financial statements show true and precise business results for the period reviewed, and that financial records have been maintained in accordance with applicable regulations. In the Republic of Serbia, unmodified opinions are divided in two groups: clean unmodified opinions and unmodified opinions with explanatory remarks. Both of these have been considered as unmodified opinions for the purpose of this research. Namely, there are 84 clear unmodified opinions (20.54\% of total sample) and 97 unmodified opinions with explanatory remarks $(23.72 \%$ of total sample). When it comes to modified opinions, the auditor will offer them in situations where they find that not enough evidence has been given to form an opinion, or when the reports are published with significant material misstatements (Ezat, 2015). Many authors have studied the correlation between audit opinion and the length of ARL. To 
Gligorić M. et al.: Audit Timeliness and Market Capitalization: Evidence from an...

be more precise, authors (Carslaw and Kaplan, 1991), (Bamber, et al., 1993), (Schwartz and Soo, 1996), (Lee and Jahng, 2008), (Che-Ahmad and Abidin, 2008), (Ahmed and Hossain, 2010), (Amirul and Salleh, 2014) have shown that auditors giving a modified opinion results in increased ARL. Authors (Ashton, et al., 1989) (Jaggi and Tsui, 1999), (Reza and Poudeh, 2014), (Banimahd, et al., 2012), (Ezat, 2015) have shown that modified opinions decrease ARL. However, authors (Lai and Cheuk, 2005), (Bonson-Ponte, et al., 2008), (Vuko and Cular, 2014) claim that there is a slight correlation between the type of audit opinion and the length of ARL. Out of 400 companies in this study, 180 companies $(45.00 \%)$ received unmodified audit opinions, while a larger number of sampled companies received modified audit opinions (220 or $55.00 \%)$. That can be seen as a red flag for the quality level of financial reporting in the Republic of Serbia. Yet, there are two explanations for these results. Public companies in Serbia are not required to receive an unmodified opinion in order to stay on the financial market. Therefore, there are fewer incentives to improve the quality of their financial reporting. Modified opinions are divided into three groups: qualified opinion, disclaimer of opinion and adverse opinion. In this research, only 7 companies were given adverse opinions (1.75\% of total sample), 71 companies received disclaimers of opinion (17.75\%) and 142 companies received qualified opinions (35.50\%). These numbers show that most of the modified opinions represent true and objective business results with certain exceptions. Therefore, it can be concluded that the quality of reporting in Serbia is actually on a higher level.

\subsubsection{Profitability}

Profitability is a measure of a company's business success and its ability to generate profit by selling products or services. In this profitability category, the following financial indicators have been analysed: Sales revenue, Net and gross margin, Earnings before interest, taxes, depreciation and amortization (EBITDA), Loss above capital (LOSS) and Sales to total assets. In order to improve the interpretation and analysis of indicators, the value of Sales revenue and EBITDA is presented in natural logarithm in order to decrease the effect of extreme values. Successful companies with high Net and Gross margin are expected to have more qualitative financial reporting and shorter ARL. A higher value of Sales to total assets indicator implies the company's ability to earn profit or to achieve better financial results with invested assets. The last indicator from this group is Loss above capital. This item in balance sheet is specific for accounting practices in Eastern European countries. If the total liabilities are greater than the value of total assets, the difference is recognized as LOSS. When companies disclose this item on their reports, it means that they are not profitable or that they have accumulated losses over several reporting periods. 
Gligorić M. et al.: Audit Timeliness and Market Capitalization: Evidence from an...

\section{Findings and Discussions}

This section of the paper represents the results in descriptive analysis, correlation analysis between given variables and multivariable regression, which provide the model and factors that anticipate the length of ARL. The following table shows the results of descriptive analysis for all the variables included in the research.

Table 2. Descriptive statistics for all research variables

\begin{tabular}{|l|c|c|c|c|c|c|}
\hline & $\mathrm{N}$ & Minimum & Maximum & Mean & Median & Std. Deviation \\
\hline $\mathrm{ARL}$ & 400 & 46 & 232 & 110.803 & 113 & 23.959 \\
\hline $\mathrm{Ind}$ & 400 & .000 & 1.000 & .443 & 0.000 & .497 \\
\hline $\mathrm{MaC}$ & 400 & 33.847 & $931,791,804$ & $9,038,527$ & 642,905 & $57,702,327$ \\
\hline MoD & 400 & .000 & 1.000 & .550 & 1.000 & .498 \\
\hline NoE & 400 & .000 & $4,045.000$ & 133.465 & 33.000 & 343.781 \\
\hline Aud & 400 & .000 & 1.000 & .075 & .000 & .264 \\
\hline Size & 400 & 8.229 & 21.940 & 14.625 & 14.694 & 1.957 \\
\hline Srev & 400 & .000 & 21.321 & 12.284 & 13.654 & 4.724 \\
\hline CRat & 400 & .001 & 149.639 & 2.602 & 1.062 & 9.256 \\
\hline NWC & 400 & $-75,558,699$ & $357,627,191$ & 554,199 & 15,240 & $21,123,883$ \\
\hline LOSS & 400 & .000 & 1.000 & .143 & .000 & .350 \\
\hline DRat & 400 & .001 & 26.456 & .741 & .414 & 1.671 \\
\hline NMa & 400 & -70.363 & 25.510 & -.808 & .007 & 6.535 \\
\hline GMa & 400 & -44.330 & .586 & -.592 & .004 & 3.157 \\
\hline EBITD & 400 & $-17,758,825$ & $370,061,356$ & $1,530,387$ & 30,324 & $18,836,663$ \\
A & & & & & & \\
\hline STA & 400 & .000 & 9.012 & .788 & 0.476 & 1.088 \\
\hline AZS & 400 & -34.600 & 249.424 & 4.122 & 1.784 & 15.872 \\
\hline ZMS & 400 & $-2,437$ & $18,235.852$ & 48.401 & -2.918 & 921.443 \\
\hline
\end{tabular}

Source: Authors research

The information provided in the Table 2 shows that the greatest number of days necessary for publishing an audit opinion is 232 , while the lowest is 46 days. Considering the average number of days for publishing audit opinions is 111 days, we can conclude that the majority of companies hit the legal deadline of 180 days. There are also auditing companies which fail to hit this deadline. These results show that the average deviance from the mean value is 24 workdays which supports the previous statement those most auditing companies meet the deadline. The obtained values for the median and the mode (114 days) are similar, which implies that the order of values is similar to normal order. However, skewness (1.002) indicates that the distribution is placed to the right, which implies that there are extreme values close to the maximum. Also, only 4 out of 400 sampled companies did not receive their audit reports by the due date. The variable industrial sector (Ind) implies that 
Gligorić M. et al.: Audit Timeliness and Market Capitalization: Evidence from an...

less than half of the studied companies belong to the service sector (NonIndustry). The financial sector has been excluded from the study.

Table 3. Pearson correlation matrix of dependent and the first part of independent variables

\begin{tabular}{|c|c|c|c|c|c|c|c|c|c|}
\hline & Ind & $\mathrm{MaC}$ & Mod & NoE & Aud & Size & SRev & CRat & NWC \\
\hline \multirow{2}{*}{ ARL } & -.06 & $-.12^{*}$ & $.24^{* *}$ & $-.12^{*}$ & .09 & -.03 & -.05 & -.09 & $-.11^{*}$ \\
\hline & .24 & .01 & .00 & .02 & .09 & .56 & .34 & .09 & .03 \\
\hline \multirow{2}{*}{$\begin{array}{l}\text { Industry } \\
\text { type }\end{array}$} & & -.06 & .04 & -.07 & -.06 & $-.27^{* *}$ & $-.28^{* *}$ & $.1^{\star}$ & -.04 \\
\hline & & .23 & .46 & .18 & .21 & .00 & .00 & .05 & .38 \\
\hline \multirow{2}{*}{$\begin{array}{l}\text { Market } \\
\text { capitalizati } \\
\text { on }\end{array}$} & & & $-.10^{*}$ & $.61^{* *}$ & $.25^{* *}$ & $.34^{* *}$ & $.19^{* *}$ & .00 & $.77^{* *}$ \\
\hline & & & .04 & .00 & .00 & .00 & .00 & .97 & .00 \\
\hline \multirow{2}{*}{$\begin{array}{l}\text { Un/Modifie } \\
\text { d opinion }\end{array}$} & & & & $-.19^{* *}$ & $-.12^{*}$ & $-.18^{* *}$ & $-.23^{* *}$ & .01 & -.07 \\
\hline & & & & .00 & .01 & .00 & .00 & .83 & .18 \\
\hline \multirow{2}{*}{$\begin{array}{l}\text { Average } \\
\text { number of } \\
\text { employees }\end{array}$} & & & & & $.16 *$ & $.46^{* *}$ & $.36 *$ & -.04 & $.43^{* *}$ \\
\hline & & & & & .00 & .00 & .00 & .40 & .00 \\
\hline \multirow{2}{*}{ Non/Big 4} & & & & & & $.29^{* *}$ & $.20^{* *}$ & -.04 & $.19^{* *}$ \\
\hline & & & & & & .00 & .00 & .43 & .00 \\
\hline \multirow{2}{*}{$\begin{array}{l}\text { Company } \\
\text { size }\end{array}$} & & & & & & & $.56^{* *}$ & -.08 & $.16^{* *}$ \\
\hline & & & & & & & .00 & .13 & .00 \\
\hline \multirow{2}{*}{$\begin{array}{l}\text { Sales } \\
\text { revenue }\end{array}$} & & & & & & & & $-.13^{*}$ & $.11^{*}$ \\
\hline & & & & & & & & .01 & .03 \\
\hline \multirow{3}{*}{$\begin{array}{l}\text { Current } \\
\text { ratio }\end{array}$} & & & & & & & & & .04 \\
\hline & & & & & & & & & .48 \\
\hline & & & & & & & & & \\
\hline
\end{tabular}

Source: Authors research

Based on the descriptive analysis, it is recorded that most of the studied companies have a modest value of market capitalization when compared to companies from the developed equity markets. The results also show that there are companies with extremely high values on the market. Therefore, there is a significant difference between the average value and median, which is also shown by standard deviation amounting to almost $€ 60,000,000$. Most of the studied companies received modified audit opinions, which implies that the quality of financial statements is at the modest level and the ARL is longer. According to the Current ratio and the Net Working Capital (NWC) variable, most legal entities are insolvent. By analysing the value for the variable Debt ratio (DRat), it can be concluded that the average indebtedness is $74 \%$. However, the authors also notice that the median is $41 \%$, which means that most companies have liabilities lower than $50 \%$, but also that 
Gligorić M. et al.: Audit Timeliness and Market Capitalization: Evidence from an...

there are companies with extreme values, which are heavily indebted. This variable can be correlated with the credit rating of the studied companies, which has been explained by Altman Z-score and Zmijewski score. Based on their value, a similar conclusion can be made when it comes to the DRat variable. The authors notice that $14.3 \%$ of companies have negative equity (LOSS), which probably refers to the previously mentioned indebted companies. Still, the sampled companies have better financial results than the rest of the Serbian industry, where $25 \%$ of companies disclose loss above capital (Stanisic, et al., 2012).

After analysing the descriptive statistics, the authors defined the correlation between the given variables. The most important is the correlation between the dependent variable $A R L$ and other independent variables. The results show that there is a statistical significance in the correlation between ARL and 12 out of 17 additional independent variables. The calculated values of Pearson correlation coefficient are shown in table 3.

Tables 3 and 4 show a matrix of correlation between dependent variable $\mathrm{ARL}$, i.e. the lag in audit reporting and the above-defined independent variables. There are several significant correlations in this context.

There is a negative correlation between $A R L$ and the independent variable Market capitalization (MaC). The high value of $\mathrm{MaC}$ implies that investors in equity markets recognize the company as successful. Therefore, it can be expected that auditor will need less time to deliver their opinion for such companies which directly impacts the length of ARL. As expected, ARL has a positive and very significant correlation with the variable Audit opinion (Mod). A modified opinion by independent auditor requires a greater number of auditing procedures and therefore more time to complete than unmodified opinion. This influences the length of ARL.

Negative correlation with $A R L$ is shown for the variable Average number of employees (NoE). According to Article 6 in Law on Accounting of the Republic of Serbia, the size of a company is defined as the average number of employees, annual revenue and the average of total assets (Law on Accounting, "Off. Gazette of RS", No. 62/2013 i 30/2018). Successful companies often have a greater number of employees. Therefore, auditors will take less time to form their opinion (due to the company's success). In addition, large entities with a greater number of employees often have a wellorganized internal audit controls and constantly improve the quality of their work. Negative correlations of $A R L$ are also found with the variable Net working capital (NWC), which measures the liquidity of a company. The higher the value of this coefficient, the greater is the company's liquidity. Therefore, ARL is shorter for these companies, as the risk of using creative accounting techniques to manipulate liquidity ratios is lower. 
Gligorić M. et al.: Audit Timeliness and Market Capitalization: Evidence from an...

Table 4. Pearson correlation matrix of dependent and the second part of independent variables

\begin{tabular}{|c|c|c|c|c|c|c|c|c|}
\hline & LOSS & DRat & $\mathrm{NMa}$ & GMa & EBITDA & STA & AZS & ZMS \\
\hline \multirow{2}{*}{ ARL } & $.16^{* *}$ & .08 & -.09 & $-.13^{*}$ & $-.12^{*}$ & $-.11^{*}$ & -.08 & -.065 \\
\hline & .00 & .13 & .09 & .01 & .02 & .03 & .09 & .197 \\
\hline \multirow{2}{*}{$\begin{array}{l}\text { Industry } \\
\text { type }\end{array}$} & $-.12^{*}$ & -.06 & -.03 & -.04 & -.05 & .06 & $.16^{* *}$ & -.047 \\
\hline & .02 & .23 & .57 & .46 & .30 & .20 & .00 & .345 \\
\hline \multirow{2}{*}{$\begin{array}{l}\text { Market } \\
\text { capitalizati } \\
\text { on }\end{array}$} & -.00 & -.01 & .01 & .02 & $.89^{* *}$ & -.01 & .03 & -.007 \\
\hline & .96 & .78 & .89 & .75 & .00 & .80 & .57 & .887 \\
\hline \multirow{2}{*}{$\begin{array}{l}\text { Un/Modifie } \\
\text { d opinion }\end{array}$} & $.21^{* *}$ & .08 & -.09 & $-.11^{*}$ & -.08 & $-.25^{* *}$ & .01 & .045 \\
\hline & .00 & .11 & .08 & .03 & .13 & .00 & .79 & .368 \\
\hline \multirow{2}{*}{$\begin{array}{l}\text { Average } \\
\text { number of } \\
\text { employees }\end{array}$} & -.00 & -.01 & -.04 & .06 & $.60^{* *}$ & $.23^{* *+}$ & -.03 & -.018 \\
\hline & .98 & .89 & .45 & .21 & .00 & .00 & .58 & .714 \\
\hline \multirow{2}{*}{ Non/Big 4} & .01 & $.12^{*}$ & .04 & -.05 & $.21^{* *}$ & .06 & -.05 & -.013 \\
\hline & .88 & .02 & .43 & .31 & .00 & .23 & .29 & .800 \\
\hline \multirow{2}{*}{$\begin{array}{l}\text { Company } \\
\text { size }\end{array}$} & -.09 & $-.15^{* *}$ & $.13^{* *}$ & $.14^{* *}$ & $.24^{* * *}$ & $-.10^{*}$ & $-.12^{*}$ & -.011 \\
\hline & .07 & .00 & .01 & .01 & .00 & .04 & .02 & .825 \\
\hline \multirow{2}{*}{$\begin{array}{l}\text { Sales } \\
\text { revenue }\end{array}$} & $-.11^{*}$ & -.08 & $.27^{* *}$ & $.35^{* *}$ & $.13^{* *}$ & $.35^{* *}$ & $-.15^{* *}$ & $-.139^{*}$ \\
\hline & .03 & .11 & .00 & .00 & .01 & .00 & .00 & .005 \\
\hline \multirow{2}{*}{$\begin{array}{l}\text { Current } \\
\text { ratio }\end{array}$} & -.09 & -.08 & .01 & -.00 & .00 & -.03 & $.86^{*+}$ & -.014 \\
\hline & .09 & .10 & .99 & .97 & 1.0 & .51 & .00 & .773 \\
\hline \multirow{2}{*}{$\begin{array}{l}\text { Net } \\
\text { working } \\
\text { capital }\end{array}$} & -.20 & $-.11^{*}$ & .05 & .08 & $.89^{* *}$ & .00 & .03 & -.005 \\
\hline & .00 & .04 & .33 & .11 & .00 & .99 & .52 & .919 \\
\hline \multirow{2}{*}{$\begin{array}{l}\text { Loss above } \\
\text { capital }\end{array}$} & & $.50^{* *}$ & $-.25^{* *}$ & $-.19^{* *}$ & -.04 & $-.11^{\star}$ & $-.15^{* *}$ & -.007 \\
\hline & & .00 & .00 & .00 & .41 & .03 & .00 & .892 \\
\hline \multirow{2}{*}{ Debt ratio } & & & $-.22^{* *}$ & $-.21^{* *}$ & -.03 & -.00 & $-.21^{* \prime}$ & .013 \\
\hline & & & .00 & .00 & .61 & .96 & .00 & .791 \\
\hline \multirow{2}{*}{ Net margin } & & & & $.74^{* *}$ & -.01 & -.09 & -.03 & -.020 \\
\hline & & & & .00 & .79 & .08 & .54 & .687 \\
\hline \multirow{2}{*}{$\begin{array}{l}\text { Gross } \\
\text { margin }\end{array}$} & & & & & .02 & $.13^{* *}$ & -.03 & -.015 \\
\hline & & & & & .67 & .01 & .57 & .768 \\
\hline \multirow{2}{*}{ EBITDA } & & & & & & -.00 & .00 & -.005 \\
\hline & & & & & & .96 & .98 & .924 \\
\hline \multirow{2}{*}{$\begin{array}{l}\text { Sales to } \\
\text { total assets }\end{array}$} & & & & & & & .01 & -.038 \\
\hline & & & & & & & .83 & .450 \\
\hline \multirow{2}{*}{$\begin{array}{l}\text { Altman Z } \\
\text { score, } \\
\text { original }\end{array}$} & & & & & & & & -.015 \\
\hline & & & & & & & & .772 \\
\hline
\end{tabular}

Source: Authors research 
Gligorić M. et al.: Audit Timeliness and Market Capitalization: Evidence from an...

Furthermore, the authors found a positive correlation between ARL and LOSS variable of very high statistical significance. Out of 400 sampled companies, $57(14.25 \%)$ companies disclose LOSS, while the other 343 companies $(85.75 \%)$ conduct business without losses. If a company has loss in their balance sheet, it means that the amount of company's assets is lower than the amount of liabilities. This implies that the company is indebted. Therefore, there is higher probability that they will go bankrupt in short period of time. As a result, the auditor needs more time to check the objectivity and validity of financial reports, as well as to determine if there is a need to deliver going concern opinion.

Table 5. Model construction process

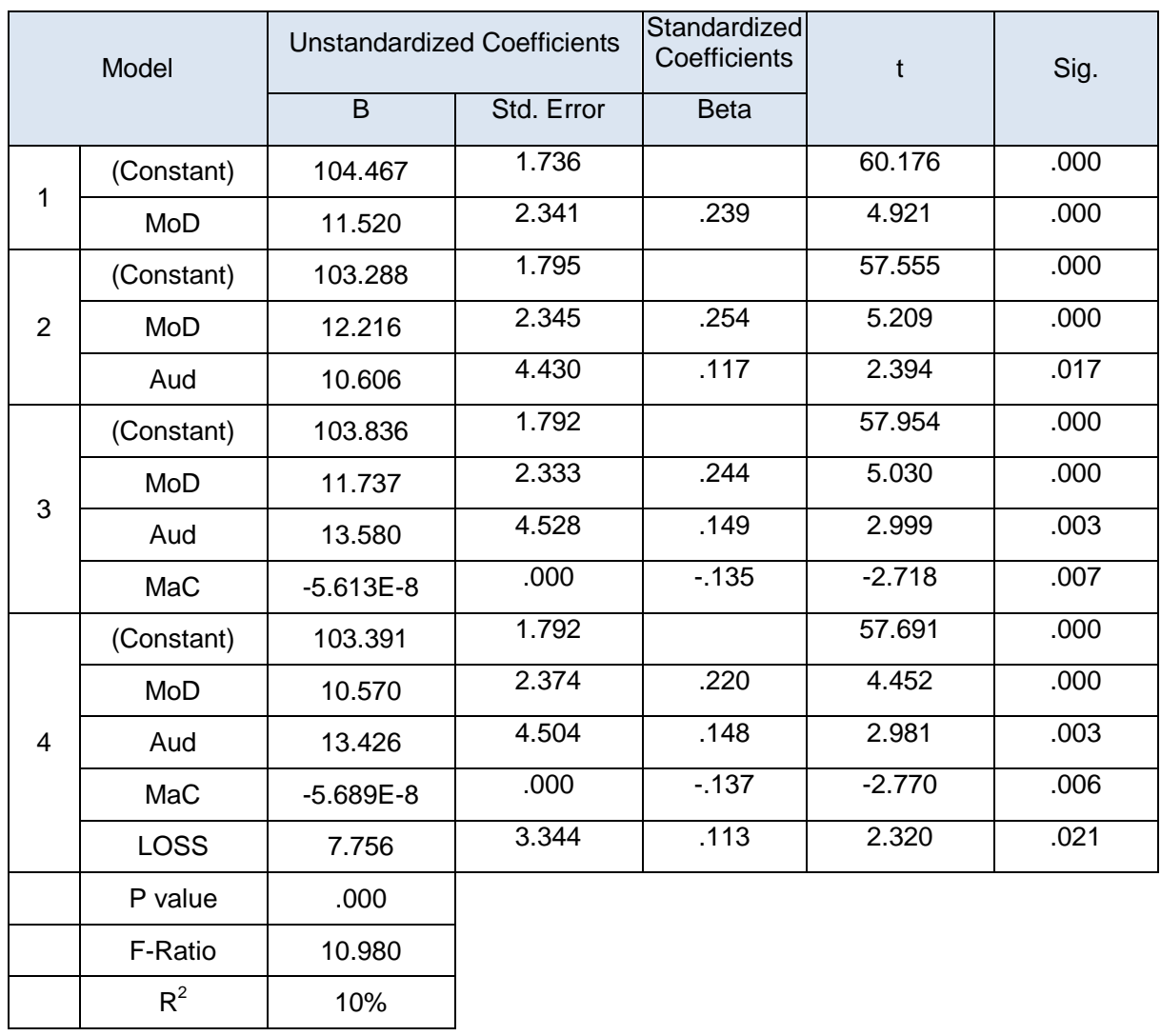

Source: Authors research 
Gligorić M. et al.: Audit Timeliness and Market Capitalization: Evidence from an...

$A R L$ and variables that indicate company profitability should have a strong correlation, i.e. more profitable companies should receive their audit opinions more quickly. This implies that the profitability measure of Gross Margin (GMa) should have a significant negative correlation with ARL and that companies with higher Gross Margins should have shorter ARL. Companies which are more profitable have shorter ARL when compared to those with lower gross margin. This is in accordance with expectations that companies with high gross margin operate successfully and that auditors will take less time to form an opinion. ARL has a negative and significant correlation with the independent variable EBITDA which is also an indicator of profitability. When it comes to the correlation between the dependent variable ARL and the variable Sales to total assets (STA), a significant negative correlation can be noticed. The indicator STA highlights more effective and more efficient usage of overall means of a company, including the amount of sales revenue. Therefore, a higher STA value displays greater earning capabilities which cause a decrease in ARL.

Table 5 shows a model highlighting variables that have a significant influence on forecasting the length of ARL. Those variables can be used to help forecast when companies listed on the stock exchange can expect an audit opinion. Multiple regression analysis is used in this model which has been shown in the following table.

Based on Table 5, it can be concluded that the given model is statistically significant, which is proven by its $P$ value. Apart from this, the F-Ratio shows that there is a low probability that they have included variables which actually do not affect the forecasted value of the dependent variable by mistake. Standard deviation in forecasting the length of $A R L$ for this model is approximately 23 days (22.844). The results show that 4 of the 17 variables that were included in study are significant for determining ARL value. One is able to notice that all independent variables in the model are statistically significant at a 0.05 level, while the variables Mod, Aud and MaC are significant at a 0.01 level. When it comes to $R 2$, the given value shows that $10 \%$ of $A R L$ is explained by the three variables. The given value is close to the amount which was reached by other authors as well (Ashton, et al., 1989), (Ahmed, 2003), (Banimahd, et al., 2012), (Enofe, et al., 2013), (Shukeri and Islam, 2012), (Carslaw and Kaplan, 1991), where the values are between 2\% and $12.6 \%$. However, there are studies where these values are significantly higher and increase to 68.6\% (Modugu, et al., 2012), (Bamber, et al., 1993), (Al-Ajmi, 2008). Based on this, the formula utilized for assessing ARL for Serbian public companies is as follows:

$$
\begin{aligned}
& A R L=103.391+10.570 \times X 1+13.426 \times X 2-0.00005689 \times \\
& X 3+7.756 \times X 4
\end{aligned}
$$


Gligorić M. et al.: Audit Timeliness and Market Capitalization: Evidence from an...

Where,

X1 - Un/Modified opinion (Mod);

X2 - Non/Big 4 (Aud);

X3 - Market capitalization (MaC);

X4 - Loss above capital (LOSS).

As expected, the type of audit opinion affects the forecast of $A R L$, and it has already been proven that there is a statistically significant correlation between variables. Many authors (Ashton, et al., 1989), (Carslaw and Kaplan, 1991), (Jaggi and Tsui, 1999), (Reza and Poudeh, 2014), (Bamber, et al., 1993), (Schwartz and Soo, 1996), (Lee and Jahng, 2008), (Amirul and Salleh, 2014), (Che-Ahmad and Abidin, 2008) have already shown statistical significance of this variable for $A R L$ on the developed and developing markets in their studies. Most experts agree that the requirement of an auditor's modified opinion will extend the period for the release of the audit opinion. However, it is important to note that, as in this study, the correlation is not always positive and in some cases the correlation can alternate between positive and negative depending on the reporting period.

It is important to note that the type of Auditor (Aud) represents a variable which is included in the model as a predictor. At the same time, this variable does not have statistically significant correlation with the dependent variable. This can be analysed in the following manner: hiring the Big 4 auditors will not increase or decrease the number of days of $A R L$, but it is a useful variable in estimating the ARL. As for the previous variable, the opinions of various authors are divided, as well as the results referring to this variable, i.e. whether it leads to an increase or a decrease of ARL. When it comes to this study, the correlation is positive, which can be understood in the following manner: the Big 4 companies have a higher risk delivering inappropriate opinions on developing markets due to generally lower performance of the companies and their higher motivation to create reports which will show the desired result. This has been supported by previous studies on developing markets (Ashton, et al., 1989), (Ahmed, 2003), (Leventis, et al., 2005), (Obradovic, et al., 2018).

When it comes to the variable of market capitalization $(\mathrm{MaC})$, its influence on ARL can be expected as it leads to a decrease in its value. In other words, companies that have higher value of market capitalization receive audit reports more quickly, while companies that have lower market capitalizations or new companies, must gain the trust of investors, which prolongs the time required to deliver the opinion. The authors in this field did not analyse this variable in correlation with $A R L$, but similar variables and the effect of 
Gligorić M. et al.: Audit Timeliness and Market Capitalization: Evidence from an...

investment potential on the timeliness of audit report were analysed in the past. Authors Pham, et al., (2014) have proven that companies with higher investment potential receive audit opinions later, which is not in accordance with the results of this study. Their study was conducted on a developed market, which may differ from developing markets. Namely, authors Sarraf, et al., (2015), Azami and Salehi (2016) conducted analysis of the influence of investment opportunities on ARL on developing markets and they obtained the same results as the ones presented in this study. To be more precise, companies with lower market capitalization may be motivated to use some legal or illegal methods of earnings management. This is why audit risk is higher for these companies and auditors have to conduct more auditing activities to gain more evidence in order to publish their opinion reasonably. As expected, the last analysed variable LOSS prolongs the value of ARL, which is in accordance with the results from other studies (Bamber, et al., 1993), (Schwartz and Soo, 1996), (Habib and Bhuiyan, 2011), (Lee, et al., 2009).

\section{Conclusions}

This paper extends prior studies about ARL and the factors which affect the timeliness of auditing reports. The contribution of this paper is the analysis of factors on developing markets, i.e. on the stock exchange of the Republic of Serbia. Furthermore, the influence of market capitalization on ARL has also been considered. Also, the originality of this study is reflected in the fact that similar studies for Eastern European countries have not been conducted yet. This study includes 400 financial reports of companies and their auditing reports for the same number of companies from the Republic of Serbia which were in business in 2017, and whose stocks are listed on Belgrade Stock Exchange. As expected, public companies follow all the deadlines for the delivery of audit reports, with an exception of only $1 \%$. Apart from this, the results of the multivariate regression show that the following variables: Audit opinion type, Engagement of non/Big 4 audit companies, Market capitalization and LOSS have a statistically significant influence on the forecast of the length of ARL.

Research results should also be helpful when it comes to prospective and existing investors in financial statements analysis, as well as when assessing success of their operations. Having in mind the research limitations, the authors highlight that the use of this model is limited to forecasting the length of ARL for public companies on developing stock markets. Namely, these limitations include the analysis of only one reporting period, excluding financial institutions from the sample. Additionally, certain variables, which are excluded from this study may also affect ARL including; auditing committee, internal audit and controls. Regarding future studies, the authors suggest 
Gligorić M. et al.: Audit Timeliness and Market Capitalization: Evidence from an...

changes regarding study sample, as well as the variables used in the study. In other words, it would be of a substantial value to analyse the influence of other variables, both financial and non-financial, which may predict the length of ARL for all legal entities. Apart from this, it would also be useful to investigate the length of $A R L$ for the surrounding countries as companies from Eastern Europe show a great investment potential.

\section{References}

Abdulla, J. (1996). The Timeliness of Bahraini Annual Reports. Advances in International Accounting, 9(1), 73-88.

Afify, H. (2009). Determinants of Audit Report Lag: Does Implementing Corporate Governance Have any Impact? Empirical Evidence from Egypt, Journal of Applied Accounting Research, 10(1), 56-86. doi: 10.1108/09675420910963397

Ahmed, A. A., \& Hossain, M. S. (2010). Audit Report Lag: A Study of the Bangladeshi Listed Companies. ASA University Review, 4(1), 49-56. doi: http://dx.doi.org/10.2139/ssrn.3406733

Ahmed, K. (2003). The Timeliness of Corporate Reporting: A Comparative Study of South Asia. Advances in International Accounting, 16(1), 17-43. doi: 10.1016/S0897-3660(03)16002-3

Akingunola, R. O., Soyemi, K. A., \& Okunuga, R. (2018). Client Attributes and the Audit Report Lag in Nigeria. Market Forces Journal of management, business and economics, 8(1), 30-41. Retrieved from http://www.pafkiet.edu.pk/marketforces/index.php/marketforces/article/view/3 54

Al-Ajmi, J. (2008). Audit and Reporting Delays: Evidence from an Emerging Market. Advances in Accounting, 24(1), 217-226. doi: https://doi.org/10.1016/j.adiac.2008.08.002

Al-Ghanem, W., \& Hegazy, M. (2011). An empirical analysis of audit delays and timeliness of corporate financial reporting in Kuwait. Eurasian Business Review, 1(1) 73-90. doi: https://doi.org/10.14208/BF03353799

Alkhatib, K., \& Marji, Q. (2012). Audit Reports Timeliness: Empirical evidence from Jordan. Procedia - Social and Behavioral Sciences, 62(1), 1342 - 1349. doi: https://doi.org/10.1016/j.sbspro.2012.09.229

Amirul, S. M., \& Salleh, M. F. (2014). Convergence to IFRs and Audit Report Lag in Malaysia. Research Journal of Finance and Accounting, 5(1), 9-16. Retrieved from

http://citeseerx.ist.psu.edu/viewdoc/download?doi=10.1.1.662.7507\&rep=rep 1\&type $=$ pdf

Ashton, R. H., Graul, P. R., \& Newton, J. D. (1989). Audit Delay and the Timeliness of Corporate Reporting. Contemporary Accounting Research, 5(2), 657-673. doi: https://doi.org/10.1111/j.1911-3846.1989.tb00732.x 
Gligorić M. et al.: Audit Timeliness and Market Capitalization: Evidence from an...

Ashton, R. H., Willingham, J. J., \& Elliott, R. K. (1987). An Empirical Analysis of Audit Delay. Journal of Accounting Research, 25(1), 92-275. doi: $10.2307 / 2491018$

Azami, Z., \& Salehi, T. (2016). The Relationship Between Audit Report Delay and Investment Opportunities. Eurasian Bus Rev, 13(5), 1-13. doi: https://doi.org/10.1007/s40821-016-0070-4

Azubike, J., \& Aggreh, M. (2014). Corporate Governance and Audit Delay in Nigerian Quoted Companies. European Journal of Accounting Auditing and Finance Research, 2(1), 22-33. Retrieved from https://pdfs.semanticscholar.org/1e82/2d48e7a660b2dbc3ae7391538898aef4 066b.pdf

Bamber, E. M., Bamber, L. S., \& Schoderbek, M. P. (1993). Audit Structure and Other Determinants of Audit Report Lag: An Empirical Analysis. Auditing: A Journal of Practice and Theory, 12(1), 1-23. Retrieved from https://search.proquest.com/openview/a8d82113df56a13c60231c2163e133e 9/1?pq-origsite=gscholar $\& \mathrm{cbl}=31718$

Banimahd, B., Moradzadehfard, M., \& Zeynali, M. (2012). Audit Report Lag and Auditor Change: Evidence from Iran. Journal of Basic and Applied Scientific Research, 2(1), 12278-12282. Retrieved from https://www.textroad.com/pdf/JBASR/J.\%20Basic.\%20Appl.\%20Sci.\%20Res. ,\%202(12)12278-12282,\%202012.pdf

Belgrade Stock Exchange. (2019). Information Services. Retrieved from https://www.belex.rs/proizvodi_i_usluge/recnik

Boljanovic, S., \& Hadzic, M. (2017). Impact of Foreign Direct Investments on Serbian Industry. Industrija, 45(3), 39-64. doi: $10.5937 /$ industrija45-13465

Bonson-Ponte, E., Escobar-Rodríguez, T., \& Borrero-Domínguez, C. (2008). Empirical analysis of delays in the signing of audit reports in Spain. International Journal of Auditing, 12(1), 129-140. doi: https://doi.org/10.1111/j.1099-1123.2008.00375.x

Carslaw, C. A., \& Kaplan, S. E. (1991). An Examination of Audit Delay: Further Evidence from New Zealand. Accounting and Business Research, 22(85), 21 32. doi: https://doi.org/10.1080/00014788.1991.9729414

Che-Ahmad, A., \& Abidin, S. (2008). Audit Delay of Listed Companies: A Case of Malaysia. International Business Research, 1(4), 32-39. doi: 10.5539/ibr.v1n4p32

Cooke, T. (1989). An Empirical Study of Financial Disclosure by Swedish Companies. New York: Garland.

Courtis, J. (1976). Relationship between Timeliness in Corporate Reporting and Corporate Attributes. Accounting and Business Research, 7(25), 45-56. doi: 10.1080/00014788.1976.9729085

Davies, B., \& Whittered, G. (1980). The Association between Selected Corporate Attributes and Timeliness in Corporate Reporting: Further Analysis. Abacus, 16(1), 48-60. doi: https://doi.org/10.1111/j.1467-6281.1980.tb00085.x

El-Dyasty, M. M. (2011). Egyptian Audit Report Lag: An Empirical Study for Audit Efficiency of Earlier Issuance versus Late Issuance. The Egyptian Journal of Commercial Studies, 35(1), 2-37. Retrieved from https://www.researchgate.net/publication/283855658_The_impact_of_audit- 
Gligorić M. et al.: Audit Timeliness and Market Capitalization: Evidence from an...

related_factors_on_audit_report_lag_for_the_Egyptian_listed_nonfinancial_companies

Enofe, A. O., Ediae, O. O., \& Okunega, E. C. (2013). Audit Delay and Audit Quality: The Nigerian Experience. Research Journal of Social Science and Management, 3(1), 75-83. Retrieved from https://www.theinternationaljournal.org/ojs/index.php?journal=tij\&page=article \&op=view\&path $\% 5 B \% 5 \mathrm{D}=2019$

Ezat, A. N. (2015). The Impact of Audit- Related Factors on Audit Report Lag for the Egyptian Listed Non- financial Companies. Journal of the Faculty of Commerce for Scientific Research, 10(1), 1-45. Retrieved from https://www.researchgate.net/publication/283855658_The_impact_of_audit_related_factors_on_audit_report_lag_for_the_Egyptian_listed_nonfinancial_companies

Givoly, D., \& Palmon, D. (1982). Timeliness of Annual Earnings Announcements: Some Empirical Evidence. Accounting review, 4(57), 486-508. Retrieved from https://www.jstor.org/stable/pdf/246875.pdf?seq=1\#page scan tab contents

Gligoric, M., Mizdrakovic, V., Kostic, M., \& Grzinic, J. (2019). Mandatory Audit: Who Performs Audits of Public Companies on Belgrade Stock Exchange? Paper presented at the International Scientific Conference FINIZ 2019, Belgrade. Retrieved from http://portal.finiz.singidunum.ac.rs/Media/files/2019/62-67.pdf

Habib, A., \& Bhuiyan, B. U. (2011). Audit Firm Industry Specialization and the Audit Report Lag. Journal of International Accounting, Auditing and Taxation, 20(1), 32-44. doi: https://doi.org/10.1016/j.intaccaudtax.2010.12.004

Hashim, U. J., \& Rahman, R. A. (2011). Reviewing the Literature on Audit Report Lag and Corporate Governance. Retrieved from https://papers.ssrn.com/sol3/papers.cfm?abstract_id=2207811

Hassan, Y. M. (2016). Determinants of Audit Report Lag: Evidence from Palestine, Journal of Accounting in Emerging Economies, 6(1),13-32. doi: 10.1108/JAEE-05-2013-0024

Hossain, M. A., \& Taylor, P. J. (1998). An Examination of Audit Delay: Evidence from Pakistan. Retrieved from http://www.mahossain.com/images/papers/Publications_in_the_Refereed_Co nference_Proceedings/34.\%20Relationship\%20between\%20Selected\%20 Co rporate\%20Attributes.pdf

Lee, H. Y., \& Jahng, G.-J. (2008). Determinants Of Audit Report Lag: Evidence From Korea - An Examination Of Auditor-Related Factors. The Journal of Applied Business Research, 24(2), 27-44. doi: https://doi.org/10.19030/jabr.v24i2.1352

Iskandar, M. J., \& Trisnawati, E. (2010). Faktor-faktor yang mempengaruhi audit report lag pada perusahaan yang terdaftar di bursa efek indonesia, Journal Bisnis Dan Akuntansi, Vol.12 No.3, 175-186. doi: https://doi.org/10.34208/jba.v12i3.215

Jaggi, B., \& Tsui, J. (1999). Determinants of Audit Report Lag: Further Evidence from Hong Kong. Accounting and Business Research, 30(1), 17-28. doi: https://doi.org/10.1080/00014788.1999.9728921

Khalid, A., \& Qais, M. (2012). Audit Reports Timeliness: Empirical Evidence from Jordan. Procedia - Social and Behavioral Sciences, 62(1), 1342 - 1349. doi: https://doi.org/10.1016/j.sbspro.2012.09.229 
Gligorić M. et al.: Audit Timeliness and Market Capitalization: Evidence from an...

Khasharmeh, H., \& Aljifri, K. (2010). The Timeliness of Annual Reports in Bahrain and the United Arab Emirates: An Empirical Comparative Study. The International Journal of Business and Finance Research, 4(1), 51-71.

Retrieved from file://Users/apple/Downloads/IJBFR-V4N1-2010-4\%20(4).pdf

Lai, K. W., \& Cheuk, L. C. (2005). Audit Report Lag, Audit Partner Rotation and Audit Firm Rotation: Evidence from Australia. Hong Kong, Kowloon.

Retrieved from https://papers.ssrn.com/sol3/papers.cfm?abstract_id=783684

Lee, H., \& Jahng, G. (2008). Determinants of Audit Report Lag: Evidence from Korea an Examination of Auditor-Related Factors. The Journal of Applied Business Research, 24(1), 27-44. doi: 10.19030/jabr.v24i2.1352

Lee, H.-Y., Mande, V., \& Son, M. (2009). Do Lengthy Auditor Tenure and the Provision of Non-Audit Services by the External Auditor Reduce Audit Report Lags? International Journal of Auditing, 19(1), 319-326. doi: https://doi.org/10.1111/j.1099-1123.2008.00406.x

Leventis, S., \& Weetman, P. (2004). Timeliness of Financial Reporting: Applicability of Disclosure Theories in an Emerging Capital Market. Accounting and Business Research, 34(1), 43-56. doi: https://doi.org/10.1080/00014788.2004.9729950

Leventis, S., Weetman, P., \& Caramanis, C. (2005). Determinants of Audit Report Lag: Some Evidence from the Athens Stock Exchange. International Journal of Auditing, 9(1), 45-58. doi: https://doi.org/10.1111/j.1099-1123.2005.00101.x

Mitic, V., Kokic, T., Mizdrakovic, V., \& Tereladze, D. (2019). Correlation between Asset Impairment and Profitability of Serbian Listed Companies. Paper presented at the International Scientific Conference FINIZ 2019, Belgrade. Retrieved from http://portal.finiz.singidunum.ac.rs/Media/files/2019/52-57.pdf

Modugu, P. K., Eragbhe, E., \& Ikhatua, O. J. (2012). Determinants of Audit Delay in Nigerian Companies: Empirical Evidence. Research Journal of Finance and Accounting, 3(1), 46-54. Retrieved from http://citeseerx.ist.psu.edu/viewdoc/download?doi=10.1.1.911.6314\&rep=rep 1 1\&type $=$ pdf

Naser, K., Abdullhameed, H., \& Nuseibeh, R. (2007). Determinants of Audit Fees: Empirical Evidance from Emerging Economies. International Journal of Commerce and Management, 17(3), 239-254. doi: $10.1108 / 10569210710833635$

Obradovic, A., Mizdrakovic, V., \& Avlijas, G. (2018). Analysis of Audit Report Lag on Serbian Stock Exchange. Paper presented at the Singidunum University International Scientific Conference, Singidunum University, Belgrade. Retrieved from https://singipedia.singidunum.ac.rs/izdanje/42937-analysis-ofaudit-report-lag-on-serbian-stock-exchange

Off. Gazette of RS No. 62/2013 i 30/2018. (2018). Law on Accounting. Retrieved from http://www.sec.gov.rs/index.php/en/regulations/legislation/bylaws/144-law-onaccounting

Off. Gazette of RS No. 62/2013 i 30/2018. (2018). Law on Auditing. Retrieved from http://www.sec.gov.rs/index.php/en/regulations/legislation/laws

Owusu-Ansah, S. (2000). Timeliness of Corporate Financial Reporting in Emerging Capital Markets: Empirical Evidence from Zimbabwe Stock Exchange. Accounting and Business Research, 30(3), 241-254. 
Gligorić M. et al.: Audit Timeliness and Market Capitalization: Evidence from an...

doi: http://dx.doi.org/10.2139/ssrn.215929

Owusu-Ansah, S., \& Leventis, S. (2006). Timeliness of Corporate Financial Reporting in Greece. European Accounting Review, 15(2), 273-287. doi: $10.1080 / 09638180500252078$

Pham, T., Dao, M., \& Brown, V. L. (2014). Investment Opportunities and Audit Report Lags: Initial Evidence. Accounting and Finance Research, 3(1), 45-57. doi: https://doi.org/10.5430/afr.v3n4p45

Reza, S., \& Poudeh, T. (2014). Audit Report Delay and Short-Term Debt Maturity, Journal of Social Issues and Humanities, 2(1), 32-36.

Sarraf, F., Dehkordi, H., \& Bakhtiar, H. (2015). Investment Opportunity in Companies and Audit Report Lags: Evidence from Iran. European Online Journal of Natural and Social Sciences, 4(1), 1515-1526.

Retrieved from http://european-science.com/eojnss_proc/article/view/4362

Schwartz, K., \& Soo, B. (1996). The Association between Auditor Changes and Reporting Lags. Contemporary Accounting Research, 13(1), 353-370. doi: https://doi.org/10.1111/j.1911-3846.1996.tb00505.x

Serbian Business Register Agency. (2018). Report on the Business Perfmance of the economy in the Republic of Serbia in 2017. Retrieved from http://www.apr.gov.rs/, accessed 22 May 2019.

Shukeri, S. N., \& Islam, M. A. (2012). The Determinants of Audit Timeliness: Evidence from Malaysia. Journal of Applied Sciences Research, 8(7), 3314-3322.

Stanisic, N., Radojevic, T., Mizdrakovic, V., \& Stanic, N. (2012). Capital Efficiency Analysis of Serbian Companies. Singidunum Journal od Applied Science, 9(2), 41-49. Retrieved from https://papers.ssrn.com/sol3/papers.cfm?abstract id=2202290

Serbian Business Registers Agency. (2018). Criteria for Classification and Limit Values for 2018. Retrieved from http://www.apr.gov.rs

Vuko, T., \& Cular, M. (2014). Finding Determinants of Audit Delay by Pooled OLS Regression Analysis. Croatian Operational Research Review, 5(1), 81-91. Retrieved from https://hrcak.srce.hr/ojs/index.php/crorr/article/view/2297 